\title{
Science, Technology and Love in Late Eighteenth-Century Opera
}

\author{
DEIRDRE LOUGHRIDGE
}

It is a tale told by countless operas: young love, thwarted by an old man's financially motivated marriage plans, triumphs in the end thanks to a deception that tricks the old man into blessing the young lovers' union. Always a doddering fool, the old man is often also an enthusiast for knowledge. Such is the case, for instance, in Carlo Goldoni's comic opera libretto Il mondo della luna (1750), in which Buonafede's interest in the moon opens him to an elaborate hoax that has him believe he and his daughters have left Earth for the lunar world; and also in the Singspiel Die Luftbälle, oder der Liebhaber à la Montgolfier (1788), wherein the apothecary Wurm trades Sophie, the ward he intended to marry himself, for a technological innovation that will make him a pioneering aeronaut. ${ }^{1}$

In both of these operas, the outlines of well-worn comic stereotypes are easily visible. ${ }^{2}$ And the very visibility of these stereotypes helps bring to view another, more broadly significant phenomenon: the reworking of operatic conventions to channel changing ideas and feelings about 'science'. For while many eighteenth-century operas lampoon devotees of bookish scholasticism, in these two cases the pursuit of knowledge appears in more modern-scientific guise: centred on observation and exploration of the natural world, its advance linked to technology and the augmentation of human powers. And whereas the pedant obsessed with antique learning was a reliable target for ridicule, science and technology represented a domain of growing importance and fashionability during the eighteenth century - a kind of activity and topic of conversation in which opera-goers were now likely to participate. ${ }^{3}$ As a result, the figure of the fool becomes complicated: in Il mondo della luna, Buonafede explores the lunar world as an attentive - though deluded - observer, while in Die Luftbälle, aeronautic pursuits are not those of the foolish old man alone: the opera's hero Karl, Sophie's true love, has himself made and flown a hot air balloon. In both

\footnotetext{
1 Fegejo 1750; Bretzner 1786, adapted as a Singspiel in 1788.

2 On the foolish philosopher or pseudo-scholar type in opera, see Farkas 1967; Hunter 1999; and Goehring 2004, esp. 53-121.

${ }^{3}$ For further discussion of the popularisation of science through literature and performance in connection with opera and musical life, see Loughridge 2016.
} 
operas, furthermore, scientific inquiry occasions special music. Indeed, replacing bookish scholasticism with observation and adventure altered the operatic potential of knowledge-pursuit; and putting music to such plots at once underlined the pleasure in scientific inquiry, and encouraged sympathy for epistemophilia.

Roy Porter has described the eighteenth century as a period of 'consolidation' for scientific knowledge: the revolutionary discoveries and methods of the likes of Galileo and Newton having already been established, the period mainly saw scientific approaches to the natural world disseminated and institutionalised across Europe. ${ }^{4}$ The 'consolidation' image, however, carries the risk of leaving out sources of resistance and acts of reinterpretation. Il mondo della luna and Die Luftbälle, I argue, show the dynamic nature of the 'consolidation' process: more than examples of opera capitalising on contemporary scientific fascinations, these operas reflect and contributed to an ongoing adjustment of earlier attitudes towards the pursuit of knowledge; in this, they belong to the history of science as much as to the history of opera. Yet such operatic cooperation in advancing scientific interests was short-lived; as we shall see, Mozart's Die Zauberflöte evidences a newfound preference for separating operatic magic from scientific achievements.

\section{Opera's Anti-Science Heritage}

From commedia dell'arte, opera inherited a robust tradition of satirising the pursuit of knowledge, at the centre of which stood the stock character of the Dottore. This 'scholar-windbag', as Peter Jordan aptly describes him, was 'an incarnated lampoon of learning, tending towards long sententious and often nonsensical speeches' intended by the speaker to display his erudition but having the opposite effect of exposing his foolishness and ignorance. ${ }^{5}$ In the case of Il mondo della luna the line of descent from the Dottore to Buonafede is clear, for Goldoni adapted the story for the opera from an earlier commedia dell'arte piece. First performed in 1684, Nolant de Fatouville's Arlequin, Empereur dans la lune - like Goldoni's opera tells the tale of a man curious about the moon, whose curiosity is exploited by others to further their own marriage interests. ${ }^{6}$ The earlier scenario begins at a telescope, as the Dottore and Pierrot debate the existence of a world on the moon. The Dottore maintains that such a world exists,

${ }^{4}$ Porter 2003. ${ }^{5}$ Jordan 2015, 66. ${ }^{6}$ See Brago 1984, 310. 
reasoning with typically comic logic: if there is twilight in the moon, there must be generation and decay; and if there is decay and generation, animals and vegetables must be born; and if animals and vegetables are born, ergo the moon is a habitable world like ours'. ${ }^{7}$ Thus even as he stands at a telescope, the Dottore privileges logic and philosophical doctrine over empirical observation. Indeed, it was a mixture of empiricism with doctrinaire logic - reasoning by analogy that if the moon has mountains like Earth it must also be inhabited like Earth - that gave birth to widespread speculation about a world on the moon in the mid-seventeenth century, and found popular expression in Bernard le Bovier de Fontenelle's naturalphilosophical work of 1686, Entretiens sur la pluralité des mondes (Conversations on the Plurality of Worlds), a text widely translated and republished throughout the eighteenth century. ${ }^{8}$

When Arlequin discovers that the Dottore intends to give his servant Colombine to an apothecary in marriage, he uses the Dottore's belief in a lunar world to secure Colombine as his own wife. Disguised as a foreigner, Arlequin presents himself to the Dottore as 'Ambassador Extraordinaire, sent by the Emperor of the moon'. Arlequin proceeds to convince the Dottore through fantastic descriptions of lunar life, as well as a faked conversation with the lunar emperor through a speaking trumpet. The Dottore listens to these voices of authority and ultimately believes what they tell him, frequently contributing his own insight - consistent with his logical deduction of a world on the moon - that 'it is just as it is here'. (In an example of circular exchange between theatre and philosophy, Gottfried Wilhelm Leibniz cited this theme from Fatouville's play - unironically - to explain his postulated 'Principle of Uniformity': 'everywhere and all the time, everything is the same as here'.) ${ }^{9}$

The pretentious erudition, the reliance on logic and doctrine, the resulting failure to distinguish reality from fantasy - these traits displayed by the Dottore in Arlequin, Empereur dans la lune remained favourite targets for satire in comic opera. The stock character of the Dottore often reappeared as a philosopher, an 'eccentric [purveyor] of arcane lore', as Edmund Goehring has described, 'who, in defiance of common sense, sought to impose a rigid system of thought upon experience.' ${ }^{10}$ An archetypal

7 'S'il y a des Crepuscules dans la Lune, bisogna ch'a vi sia una Generation, \& una Corrution; e s'al ghé una corrution, \& una generation, bisogna ch'a ve nasca dei Animali, e dei Vegetabili; e s'al ghe nasce dei animali, e dei vegetabili, ergo la Luna é un Mondo abitabile com'al nostro.' Fatouville 1721, 180-1.

${ }^{8}$ On the history of the idea of a world on the moon, see Crowe 1986, esp. 9-21 and 59-73.

9 Letter to Sophie Charlotte, 8 May 1704, cited in Lodge 2004, $200 .{ }^{10}$ Goehring 2004, 54. 
example comes from Giovanni Bertati's I filosofi immaginari. Composed by Giovanni Paisiello initially for the court of Catherine II in St Petersburg in 1779 , the opera had several dozen performances in German adaptation between 1781 and 1803 in cities including Vienna and Dresden, under the titles Die engebildeten Philosophen and Die engebildeten Astrologen. ${ }^{11}$ The plot is preserved across the opera's various versions: the father Petronio is a Dottore-type character, whose primary concerns are 'scholarship and science'. ${ }^{12}$ One of his two daughters follows in his footsteps: Cassandra is interested in philosophy and rejects the idea of marriage. Clarice, on the other hand, regards philosophy as useless and is concerned primarily with marrying her lover, Giuliano. Philosophy, in this story, is scholastic and logical, disengaged not only from the social world but also from empirical observation. As Cassandra declares, she is 'already accustomed to treating sense perception with scorn'. ${ }^{13}$ Her métier, like her father's, is to seek knowledge in the pages of books by such authorities as Plato and Descartes. Musically, their epistemophilia is depicted through marchstyle arias that capture their pomposity, or patter arias that heighten the ridiculousness of their pseudo-erudite speech. ${ }^{14}$

Concurrent with such depictions of the philosopher in the latter half of the eighteenth century, meanwhile, were portrayals of a new species of knowledge-seeker. In Il mondo della luna, Goldoni transmuted the scholarwindbag Dottore into someone curious to gain knowledge through sensory observation. At the start of the opera, Buonafede does not already believe there must be a world in the moon. Instead he visits the astronomer Ecclitico in order to inquire what the moon is. Ecclitico has just built a giant telescope, and tells Buonafede he has discovered that on the moon is another inhabited world. This notion had largely fallen out of favour by the mid-eighteenth century, as mounting empirical evidence failed to support it. ${ }^{15}$ Buonafede is thus surprised by Ecclitico's claim, and remarks that only his grandmother (a figure of the past) had ever spoken of such things. But when he looks through Ecclitico's telescope and sees people interacting not

11 See the entry for Paisiello's I filosofi immaginari in Die Oper in Italien und Deutschland zwischen 1770 und 1830, www.oper-um-1800.uni-mainz.de/einzeldarstellung_werk.php? id_werke=317\&herkunft=; and Hadamowsky 1966, 1:34.

12 'scienza, e dottrina'; 'Gelehrsamkeit und Wissenschaft'. Bertati 1784, 19; 1783, 24.

13 'E a trattar con disprezzo / I sensi e la material io già mi avvezzo'; 'bin schon gewohnt, die sinnliche Empfindung mit Verachtung zu unterdrücken'. Bertati 1784, 7; 1783, 6.

14 See Hunter 1999, 110-24; and Goehring 2004, 78-82.

15 See Crowe 1986, 59-73; as Crowe observes, refraining from speculation about lunar inhabitants was crucial for astronomers to establish a professional reputation by the latter half of the eighteenth century. 
at all like they do on Earth, he immediately accepts the visual evidence. Unbeknownst to Buonafede, his faith is misplaced: Ecclitico is a fraudulent astronomer and his telescope a fake. What Buonafede sees through the instrument is not a world in the moon, but an illuminated machine with moving figures, hanging just beyond the end of the optical tube. ${ }^{16}$

The scene of telescopic observation initiates the moon-world hoax, undertaken for the same reason as in Arlequin, Empereur dans la lune. But in this case, the hoax involves Buonafede's extensive empirical investigation of the lunar world. At the end of Act I, Buonafede drinks a sleeping potion believing it will transport him to the moon. At the start of Act II he wakes up on what he takes to be the world in the moon - in fact Ecclitico's garden, decorated with 'extravagances' (stravaganze) to give it an appropriately exotic appearance. Guided by Ecclitico, Buonafede observes the lunar environment - and Goldoni's libretto calls for particular nature sounds. 'Listen to the harmonies from those saplings shaken by quick breezes,' Ecclitico instructs Buonafede; the subsequent stage direction reads, 'a short concert begins with violins and oboes in the orchestra, echoed by hunting horns and bassoons from behind the scenery'. Other musical stage-directives include 'nightingales are heard singing', and 'offstage echoes answer from all sides'. Unlike the view through the telescope, which only Buonafede can see, these sounds give Buonafede and opera spectators alike the opportunity to observe lunar nature - and the composer the opportunity to render that nature either patently ridiculous or seductively otherworldly (and hence to characterise Buonafede as a total fool or a more sympathetic dupe).

Throughout his telescopic and first-hand encounters, Buonafede finds lunar behaviour to be very different and preferable to that on Earth (a change from the Dottore's doctrine 'it is just as it is here'). To the harmonious tree rustling, Buonafede responds with typical enthusiasm: 'Bravo! Bravissimo! In this world the trees can play much better than our musicians.' In the tradition of the Dottore, Buonafede's efforts to acquire and display knowledge reveal his comical ignorance and gullibility. But whether one laughs at or sympathises with Buonafede depends much on the music, and how familiar or exotic, patently ridiculous or beautifully otherworldly, it makes Ecclitico's tricks seem.

First set by Baldassare Galuppi for performance in 1750, Il mondo della luna subsequently received numerous new settings (and numerous textual

16 For further discussion of the relationship between Goldoni's telescope scene, Haydn's setting and popular scientific culture, see Loughridge 2016, 25-45. 
revisions) into the 1790 s. $^{17}$ Galuppi's version, composed for the carnival season in Venice, presents no major musical surprises, investing Ecclitico's lunar garden with little sense of otherworldliness, and preserving Buonafede in the familiar role of the foolish old man. Later composers, by contrast, seized upon, and even expanded, the opportunity to portray an exotic lunar soundscape. When Haydn and Paisiello composed versions of Il mondo della luna, in 1777 and 1783 respectively, each departed from Goldoni's instructions in ways that encourage opera spectators to share Buonafede's delight and wonder at 'lunar' phenomena.

Haydn's Act II starts with a Sinfonia that previews some of the nature sounds that Buonafede will encounter after he wakes (Example 8.1). The Sinfonia begins with material from the tree branch symphony (bb. 1-8). The phrase segues into an idea (bb. 8-11) that will recur as singing birds in Buonafede's aria 'Che mondo amabile', where he lists the delightful things he has seen and heard on the moon ('the trees play music, the birds sing, the nymphs dance, the echo replies'). Through differences in orchestration between the Sinfonia and these later instances, Haydn first introduces opera spectators to a strangely beautiful 'lunar' environment, then presents Buonafede with more ordinary, even ridiculous 'lunar' sounds at odds with his enthusiasm. In the Sinfonia, for instance, the melody from the tree symphony is scored for violins with a solo violin added an octave above, imparting a lustrous sheen. The tree symphony Buonafede applauds, by contrast, features a melody on bassoon, an instrument often spotlighted for comedic effect (Example 8.2).

In Buonafede's aria 'Che mondo amabile', the birdcalls are scored for flutes, oboes, bassoons, and horns, accompanied by Buonafede's whistling (Example 8.3). In the Sinfonia, they are scored for the special effect of strings playing flageolet - that is, playing harmonics by lightly stopping the string at natural nodes, thereby yielding a different, airier tone. Flageolet harmonics were so called because they were thought to sound like the flageolet, a wooden predecessor of the tin whistle. ${ }^{18}$ By setting birdsong for strings playing flageolet in the Sinfonia, Haydn thereby called for an imitation of an imitation. The result is appropriately distanced from the original: the naturally unequal strengths of the violin's harmonics turn the descending thirds on the page into ascending fourths in performance, transforming the most stereotypical birdcall into something hardly

17 See Polzonetti 2011, 29-32.

18 Jean-Joseph Cassanéa de Mondonville introduced violin harmonics in Les Sons harmoniques: Sonates à violon seul avec la basse continue, Op. 4 (Paris, c.1738), explaining how to produce them in an introduction and featuring them in the sonatas. 
Example 8.1 Haydn, Il mondo della luna, Act II, Sinfonia, bb. 1-10. (Joseph Haydn Werke, series 25, volume 7/2, ed. Günther Thomas (Munich: Henle, 1979).) Used by permission
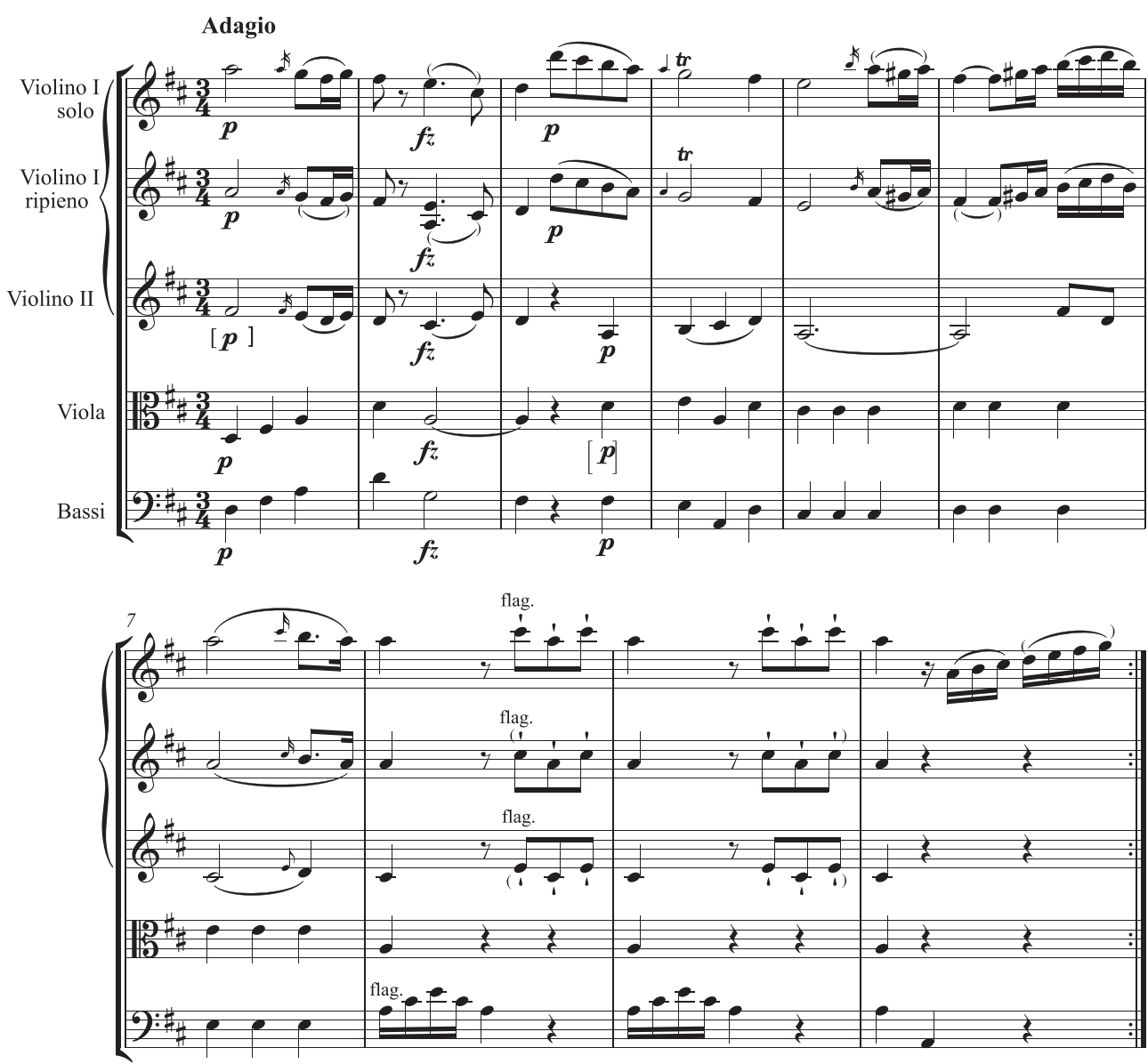

suggestive of birdcall at all. It seems altogether fitting to respond to these lunar birdcalls as Buonafede would - to find them delightful and different, perhaps even better, than any birdsongs heard on Earth. Haydn thus grants opera spectators two sources of pleasure: first in experiencing a fantastic lunar world for themselves, and subsequently in knowing better than Buonafede as he falls for the illusion.

In Paisiello's setting, an instrument unmentioned by Goldoni defines the sound of the lunar world: the still-uncommon clarinet. ${ }^{19}$ The instrument is

19 Paisiello produced Il mondo della luna in a number of versions; here, I refer to the festa teatrale version performed in St Petersburg, 1783, which served as the basis for the version performed in Vienna in 1786. 
Example 8.2 Haydn, Il mondo della luna, Act II, 'tree symphony', bb. 1-14

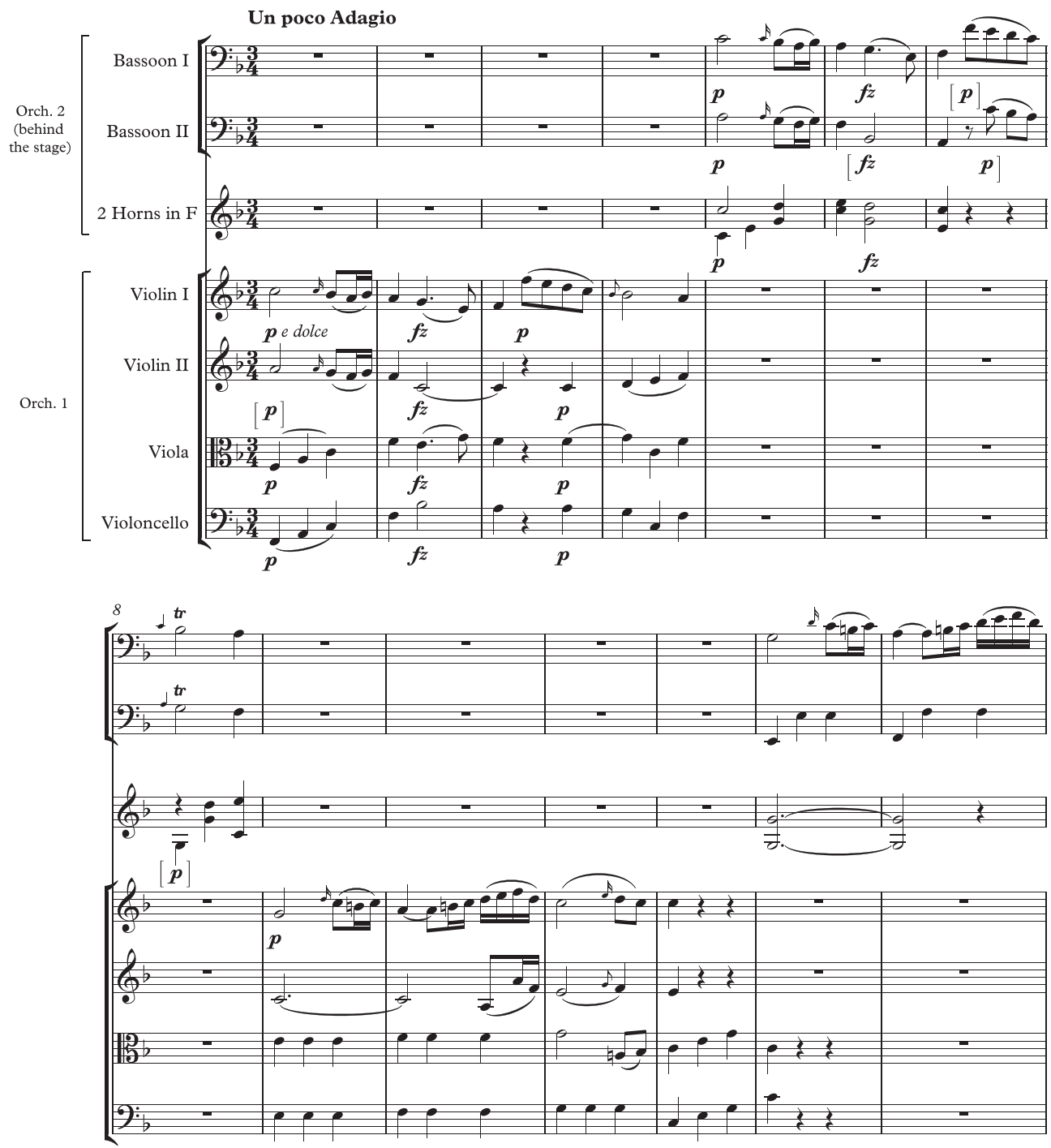

reserved for numbers that conjure the lunar soundscape, and combines with horns and bassoons to form wind ensembles of a kind that carried magical associations in eighteenth-century opera. ${ }^{20}$ Disregarding Goldoni's specifications for the tree symphony, Paisiello scored the number for a wind quartet of clarinet, bassoon and two horns. Paisiello also

${ }^{20}$ See Buch 2008. 
Example 8.3 Haydn, Il mondo della luna, Act II, 'Che mondo amabile', bb. 44-49

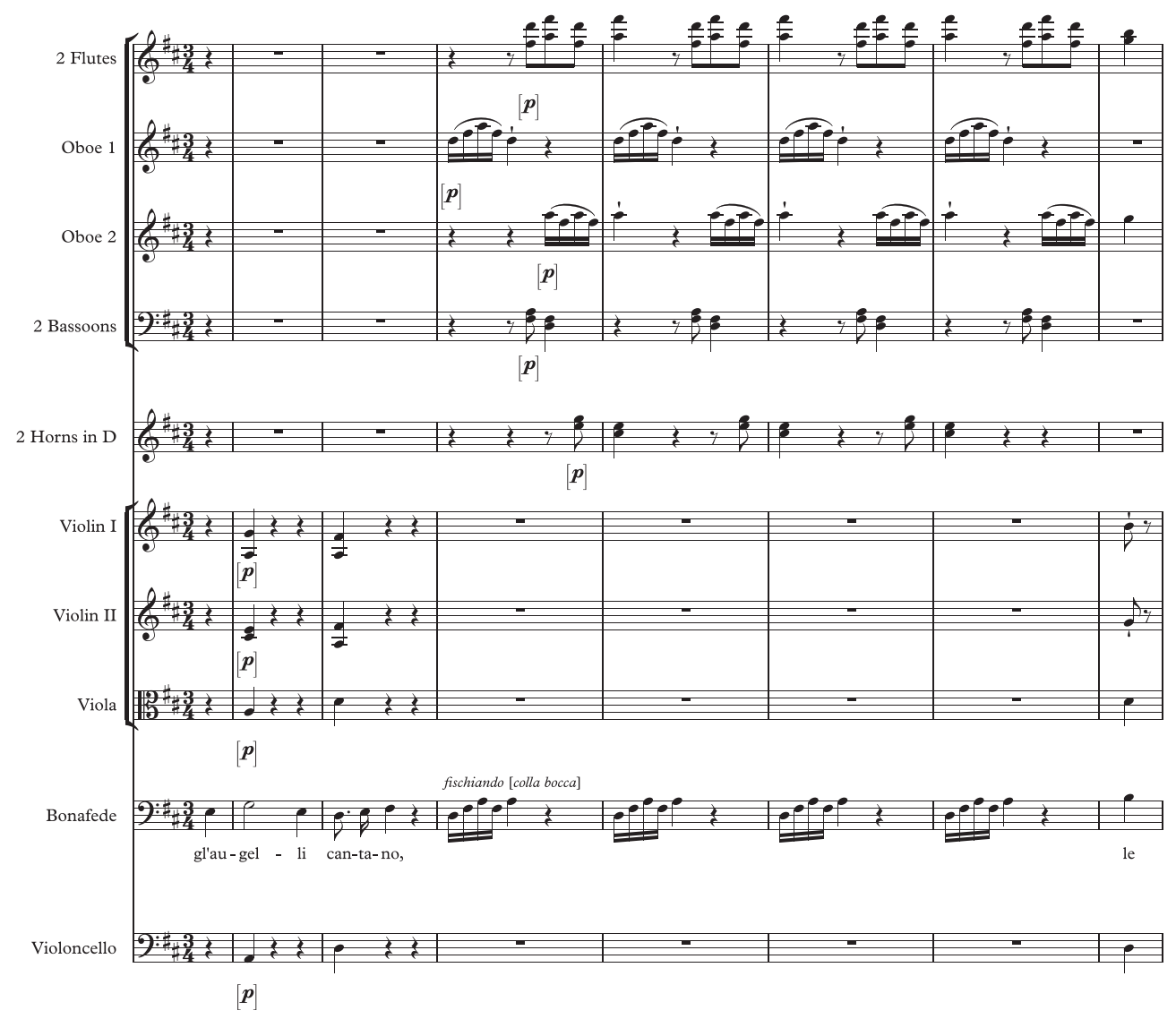

added an instrumental number to depict the 'healthy' lunar air that Ecclitico points out to Buonafede (Example 8.4). Scored for two wind quintets, each composed of two clarinets, bassoon and two horns, the 'healthy air' number features a back-stage wind ensemble echoing the one in the pit (the spatialised sound, here as elsewhere, contributing to the sense of being in another world). Paisiello thus supplied lunar music at which opera spectators could marvel along with Buonafede, and through which they might gain sympathy for his enthusiasm.

Haydn composed Il mondo della luna for a wedding celebration at Esterháza, and Paisiello his as a festa theatrale for the court of Catherine II in St Petersburg. Adding musical to visual splendour may thus have been uppermost on these composers' minds as they marshalled their instrumental resources to heighten the music-theatrical spectacle of Il mondo 
Example 8.4 Paisiello, Il mondo della luna, Act II, 'air', bb. 1-21. Österreichische Nationalbibliothek Musiksammlung, Mus.Hs.17806/2
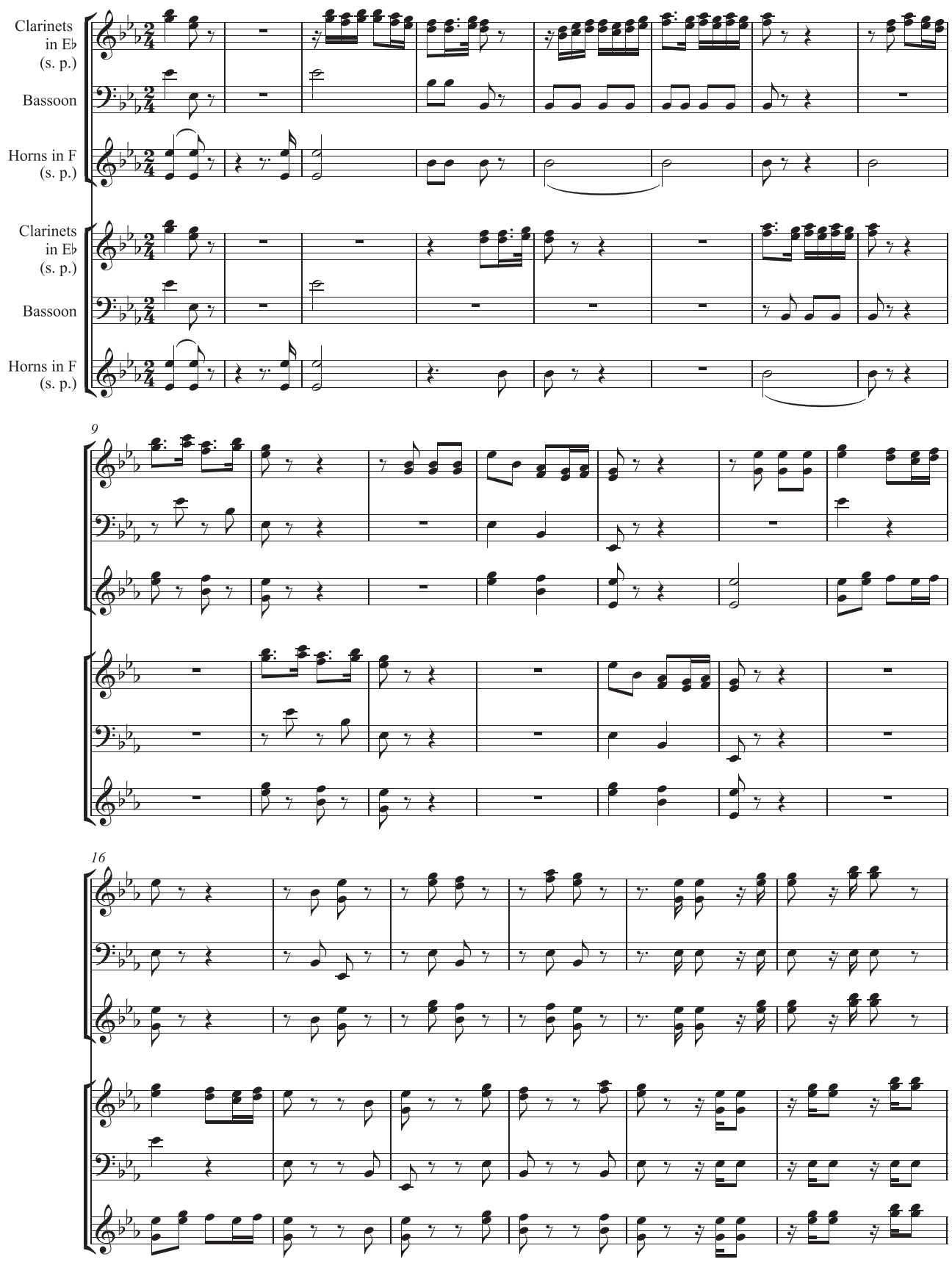
della luna. But Haydn's and Paisiello's choices also had ramifications for the characterisation of Buonafede and his scientific curiosity, and reflect a new scientific consciousness in opera - one cognisant of the spectacular potential of sensory observation and its technological enhancements. These composers discovered this potential in a mid-eighteenth-century libretto still strongly marked by opera's anti-science heritage. But librettists working in the 1780s and 1790s found new source materials in the scientific developments of their day. In fact, the same year that Paisiello composed $\mathrm{Il}$ mondo della luna to sonify the lofty perspective of the moon, scientific consciousness received further impetus from a new technological innovation: the hot air balloon.

\section{Approaching the Gods}

'Thanks to the Montgolfiers, whom genius inspires ... the feeble mortal can approach the gods', a poet observed on the occasion of a balloon launch at Lyon in January $1784 .^{21}$ The Montgolfier brothers had launched the first hot air balloon before a crowd of 60,000 spectators at Versailles in June 1783, and sent up the first manned balloon - flown by Pilâtre de Rozier - a few months later. News of the hot air balloon quickly spread throughout Europe, as did ventures in flight.

Johann Wolfgang von Goethe described hot air balloons as experiments from a time 'when the scientific world was busily occupied with determining the different kinds of air'. ${ }^{22}$ He might equally have noted the wider world's preoccupation with the spectacle of hot air balloon launches: a spectacle that could turn operatic. For instance, at the ascent of the 'Marie Antoinette' that took place at Versailles on 23 June 1784 to entertain visiting royalty from Sweden, musicians played the overture from PierreAlexandre Monsigny's comic opera Le Déserteur (1769). More common are references to unidentified military music or cannon fire; but celebratory sounds regularly complemented the awe-inspiring sight of a balloon ascending into the heavens. ${ }^{23}$

As the celebratory atmosphere at balloon launches suggests, aeronauts were cultural heroes. They became a focus of national sentiment, arousing

21 Quoted in Darnton 1968, 20.

22 'als die naturforschende Welt sich eifrig beschäftigte die verschiedenen Luftarten zu erkennen'. Goethe 2014, 53.

23 See the numerous contemporary reports translated in Jobé 1971. 
pride in the achievements of one's countrymen, a competitive desire to surpass other nations, and prompting races to become the 'first' at various localities. The winner of many of these races was J.-F. Blanchard, a French mechanic who became an aeronaut by financing his flights through ticket subscriptions. With this entrepreneurial approach, Blanchard travelled throughout Europe introducing people to the phenomenon of human flight. He cultivated the spectacular side of ballooning, fashioning himself a brave explorer more than a natural philosopher. Sometimes, however, he was joined by a scientific companion: the physician John Jeffries accompanied Blanchard on certain flights, and recorded such metrics as temperature and barometric pressure. ${ }^{24}$ On 3 October 1785, Blanchard ascended in a balloon at Frankfurt am Main to become the first to fly in Germany. Though he advertised himself as a 'French aeronaut', he also appealed to national feelings, as in a promotional poem that espoused the greatness of air balloon flight and proclaimed 'they were Germans / Who recognised all this'. ${ }^{25}$

To become the first German to fly remained a prized title - one that the Baron Lütgendorf sought to claim on 24 May 1786. Much promotional material was published ahead of the launch. One pamphlet (reproduced in Figure 8.1) celebrates Lütgendorf as the first German aeronaut, with verses such as, 'Hark sons of Germany! A German will dare / To be carried by an air balloon through the air: / Baron von Lütgendorf will become Germany's Blanchard / And invites you to admire the show and regard.' The poem concludes by calling upon those who share scientific interests as well as sensibility to attend the launch, and linking their attendance to civic pride: 'O come, ye who honour your arts / Ye who nurture your knowledge and good feelings / Come, ennoble our city, and ennoble the balloon! / And think - a German flies, and fame is his only reward!'26

The competitive and potentially nationalistic nature of ballooning, as well as the question of reward, runs through Christoph Friedrich Bretzner's Singspiel Die Luftbälle, oder Der Liebhaber à la Montgolfier. As the story

${ }^{24}$ See Gillespie 1984. On the spectacular-cum-scientific culture of hot air balloons, see also Keen 2006, Holmes 2008 and Brant 2011.

25 'Das waren Deutsche zwar, / Die alles dies erkannten'. Quoted in Westheim 1908, 310.

26 'Auf, Söhne Deutschlands, hört! Ein Deutscher wird es wagen, / Durch einen Luftballon sich durch die Luft zu tragen: / Baron von Lütgendorf wird Deutschlands Blanchard seyn, / Und ladet euch zur Schau und zur Bewund'rung ein.'; 'O, kommet doch herbey, ihr, die ihr Künste ehret, / Ihr, die ihr Wissenschaft und Schöngefühle nähret, / Kommt, adelt unsre Stadt, und adelt den Ballon! / Und denkt - Ein Deutscher fliegt, und Ruhm nur ist sein Lohn!' [unsigned] 1786, $[1,3]$. 


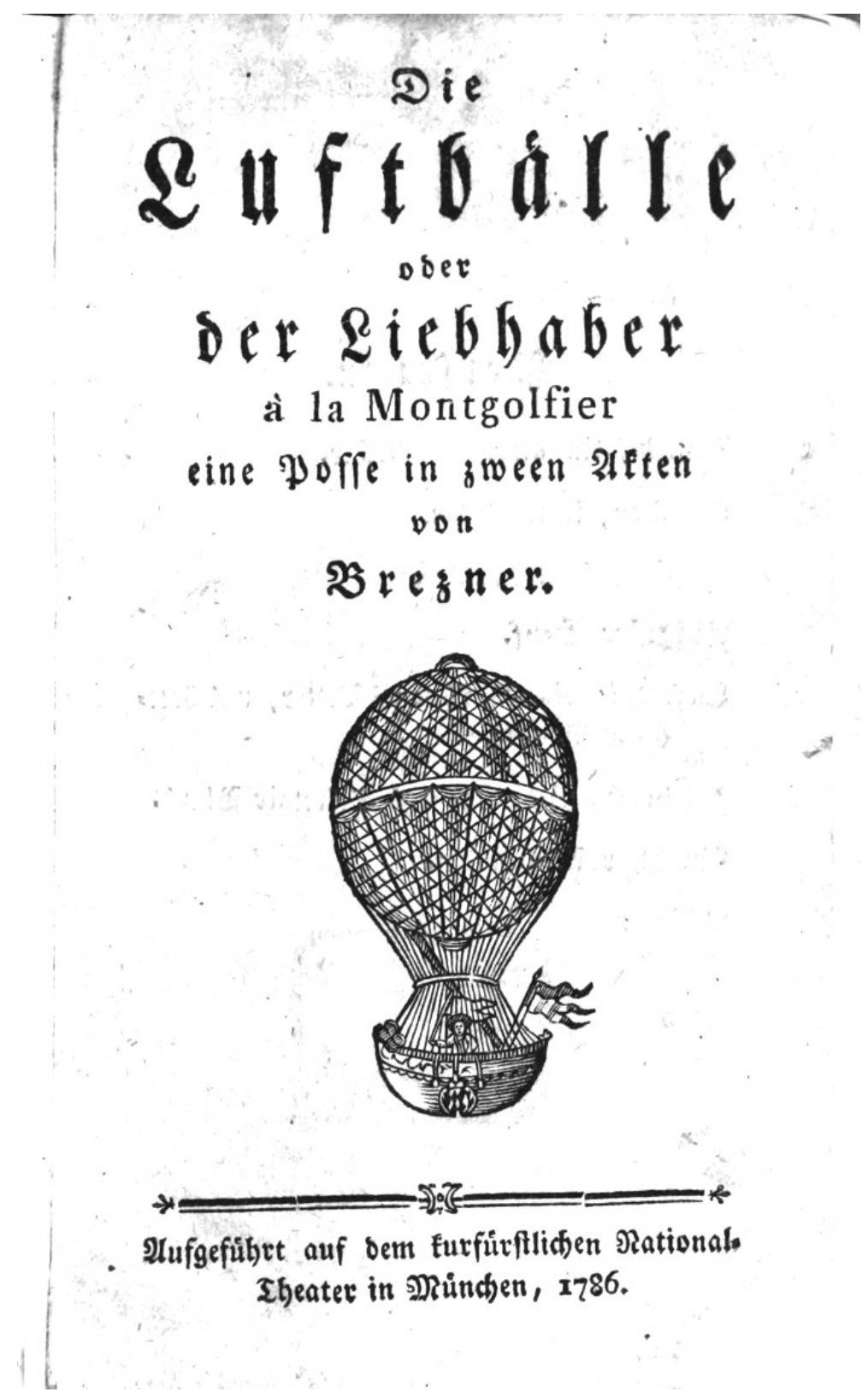

Figure 8.1 Christoph Friedrich Bretzner, Die Luftbälle, oder der Liebhaber à la Montgolfier (Leipzig: Friedrich Gotthold Jacobaer, 1786), title page. Bayerische Staatsbibliothek München, P.o.germ. 175, urn:nbn:de:bvb:12-bsb10106328-3. 
starts, Sophie laments the absence of her true love Karl, and her impending marriage to her guardian, the apothecary Wurm. Karl's sister Lottchen, however, produces a letter for Sophie from Karl, in which he announces he is on his way to her in a hot air balloon. As Sophie worries over Karl's safety, Wurm enters, talking about the 'amazing thing' ('unglaubliche Dinge') that soon everyone will be able to read about in the newspapers. In guessing what 'amazing thing' Wurm has in mind, Lottchen proposes both traditional alchemical pursuits as well as a more modern, institutional achievement: perhaps Wurm has invented a universal medicine, become a member of the Academy of Sciences in Paris, or discovered the philosopher's stone and can now make gold. But it is none of these 'trifles'. Rather, with the help of Magistrate Senf, Wurm has readied and is about to fly a hot air balloon.

Wurm's casting as an apothecary resonated with contemporary life as well as satirical tradition. Goethe recorded the efforts of local Weimar apothecary Wilhelm Sebastian Buchholz to keep up with the latest scientific experiments by launching a hot air balloon in 1784, at first unsuccessfully, but ultimately getting off the ground. ${ }^{27}$ Wurm is interested less in keeping up with current science, however, than in becoming famous as the first great German aeronaut. Modelling himself on 'the brave Blanchard', Wurm intends for Senf and himself to become famous as the first Germans to fly. Senf, meanwhile, believes they will make a trip to the moon, and has grand plans for their pioneering space exploration. His projected studies range from the natural-scientific to the cosmological and anthropological, with topics including the spots on the moon, the 'existence and being of more worlds', and the character of those worlds' peoples and societies.

What starts as a mutually beneficial collaboration between Wurm and Senf turns acrimonious when - in the course of pompously describing the celebrity they will enjoy after their flight - Wurm inadvertently insults Senf with the remark that he will no longer be a 'miserable, simple Magistrate' ('elenden simplen Magister'). Lottchen interrupts the ensuing spat by letting slip the secret that her brother Karl has made an air balloon. Wurm and Senf each rush to make themselves indispensable to the younger aeronaut. Senf asserts that a young man like Karl needs a savant (Gelehrten) like him. He envisions himself conducting experiments while Karl steers: he will be the Dr Jeffries to Karl's Blanchard. Wurm, on the

27 Goethe 2014, 53-4. 
other hand, maintains that Karl, being a young man, needs him as a sponsor.

Once Karl arrives - waving 'the flag of love' - Lottchen hatches a plan to exploit Wurm's aeronautic dreams in order to unite Karl and Sophie. It is a simple deception: Karl tells Wurm and Senf that he has invented a steering mechanism and is going to the moon since, having no hope of marrying Sophie, there is nothing for him on Earth. At this, Wurm offers to let Karl marry Sophie if he will tell Wurm how to steer the balloon and let him take credit for the invention. At the ensuing launch, however, Wurm and Senf go up and quickly fall back to earth, while Karl and Sophie fly away in Karl's balloon, to live happily ever after.

Because Karl is a successful aeronaut, Wurm and Senf embody less lampoons of learning than of incompetence; what comes in for satire is not the pursuit of knowledge so much as the selfish motivations for such pursuit, and the character of the pursuer. Wurm spells out the values he stands for early on, telling Sophie and Lottchen: 'head, head, head, head must one have! Sciences, talent, erudition, spirit of invention! ${ }^{28}$ Karl exposes the incompleteness of these values. He is, as Lottchen says, a genius, whose ballooning will probably earn him a title, pension and fame. But his intellectual pursuits and economic success flow from his bravery and love. As Lottchen describes Karl, he has a 'brave, adventurous head' (kühner unternehmender Kopf). And Karl calls his hot air balloon not a ticket to fame and fortune but his rescuer, saying he has it to thank for the happiness of his life - his reunion with Sophie. If there is a secure moral reading of all this, the story arguably draws distinctions between laughable and admirable forms of scientific venture, finding it possible for intellectual genius to be united with a warm heart and brave soul.

Bretzner established himself as a popular librettist in 1779, with the publication of four operettas. Today, the Leipzig-based writer is chiefly remembered as the librettist whose Belmont und Constanze, oder Die Entführung aus dem Serail (written for the composer Johann André and published in 1781) was 'freely adapted' by Gottlieb Stephanie to become Mozart's Entführung aus dem Serail (1782). ${ }^{29}$ But Die Luftbälle he wrote not as an operetta but rather as a spoken play - a two-act farce (Posse). The play was performed in Hamburg and Breslau in the summer of 1785,

28 'Kopf, Kopf, Kopf muß man haben! Wissenschaften, Talente, Gelehrsamkeit, Erfindugsgeist!' Bretzner 1786, 13.

29 The title page of the 1783 Entführung aus dem Serail libretto reads 'nach Bretznern frey bearbeitet'. 
according to Bretzner's preface to the first edition, which was printed in Leipzig the following year. ${ }^{30}$ While this edition sees a 'choir of musicians with trumpets and drums' participate in the climactic balloon launch, there are no numbers for the main characters to sing, and no composer is credited.

That Die Luftbälle would be adapted as a Singspiel is not surprising, given Bretzner's popularity as a librettist, the common plot elements, and the musico-spectacular appeal of the hot air balloon. In 1788, song texts 'from the Singspiel' Die Luftbälle were printed in Hamburg, under the names of Bretzner as author and Ferdinand Fränzl as composer. ${ }^{31}$ For Fränzl, Die Luftbälle was his first stage work. After he wrote the music in Strasburg, where he studied composition with Franz Xaver Richter and Ignaz Pleyel, the Singspiel premiered at the Mannheim Nationaltheater on 15 April 1787 (where Fränzl's father - also a composer and violinist - was musical director). It continued to be performed there until 1795, and also had a Munich premiere in 1788 , though the music seems never to have been published. ${ }^{32}$ Unlike the free adaptation of Bretzner's Belmont und Constanze, the adaptation of Die Luftbälle to the musical stage stayed true to Bretzner's plot, the song texts being inserted between or replacing the spoken text. The narrative fidelity of the adaptation brings into focus the effects of 'opera' on the telling - of song texts and music on the tone and messages of the stage production.

As one might expect, Fränzl musically heightened the spectacle of the hot air balloon. The launch scene involves celebratory music likely akin to that provided by the choir of musicians Bretzner had scripted, and by musicians at actual balloon launches. But in addition, the scene features dramatic action music. The balloons ascend to the accompaniment of a seventeen-measure pedal point on $\mathrm{D}$ major, with gradually increasing activity and dynamic level in the orchestra (Example 8.5). It is music of a sort used to represent sunrises, as well as marvellous entrances like that of the Queen of the Night in Mozart's Die Zauberflöte. The conventionality of the musical gesture serves to liken the hot air balloon launch to such

30 A playbill gives 23 May 1785 as the date of first performance in Hamburg, according to the catalogue of the Staats- und Universitätsbibliothek Hamburg. This date precedes de Rozier's balloon accident, which is referenced in the added song texts.

31 Whether these song texts were penned by Bretzner or were the work of another, uncredited author is unclear. Friedrich Walter proposed Friedrich Schiller as author, citing a letter of 17 May 1786 in which Schiller mentions meeting Ferdinand Fränzl, and having completed some operetta texts; see F. Walter 1909.

32 See F. Walter 1899, 399; Bolongaro-Crevenna 1963, 249. 
Example 8.5 Ferdinand Fränzl, Die Luftbälle, oder Der Liebhaber à la Montgolfier (1785), Act II finale; instrumental ritornello while the balloons ascend. Staats- und Universitätsbibliothek Hamburg Carl von Ossietzky, ND VII 130: 1
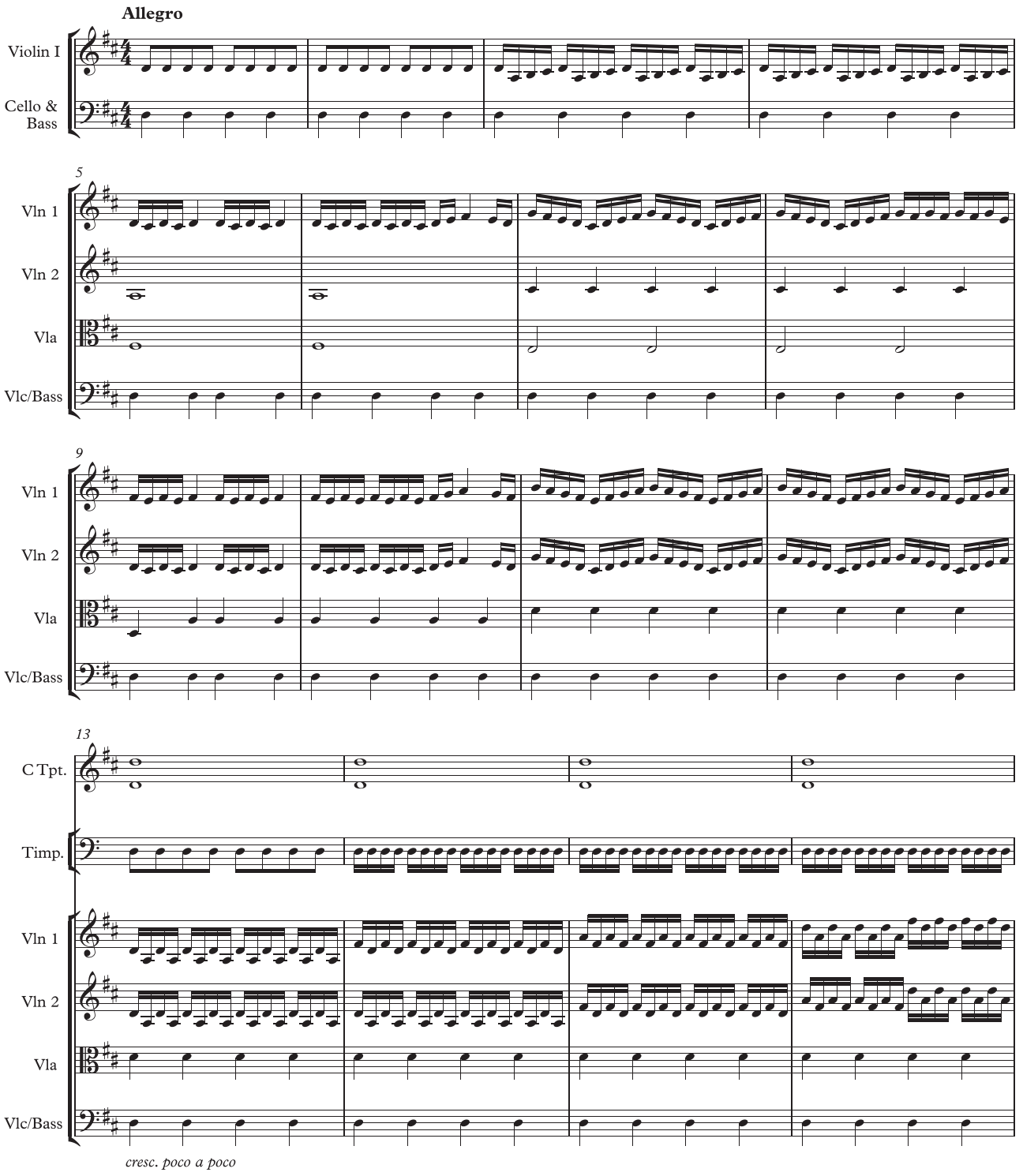

natural and fantastic phenomena, and to invest the aeronautic technology with a similar sense of awesome power.

Other changes come with the endings to each act, which were redesigned to suit the conventions of operatic finales. The first act of the play ends with 
Wurm and Senf making amends and exiting arm-in-arm with a renewed commitment to their venture. By contrast, the Singspiel Act I finale proceeds from an added plot element: news of a hot air balloon accident. Lottchen reads the story of a fallen aeronaut from a newspaper, and shocks Wurm and Senf with the revelation that the victim was none other than Pilâtre de Rozier, the first man to ascend in a hot air balloon. The accident in question took place on 15 June 1785, when de Rozier attempted to fly across the English Channel with a new balloon design combining inflammable gas' (hydrogen) and hot air. When the balloon caught fire, Pilâtre and his flight companion plummeted to their deaths, becoming the first aeronautic casualties - to widespread lamentation. ${ }^{33}$ The finale thus amplifies the idea of mortal risk whose focal point in the play is Sophie's concern for Karl's safety. And the news report leads to an added moral that Sophie, Lottchen, Wurm and Senf sing together to end the first act: 'the higher the flight, the further the fall' ('Je höher der Flug, je tiefer der Fall'). Fränzl's setting dwells on the line: sung in unison and in imitation, it homes in on the danger inherent in scientific advance. But as the end of the first act, it is a sentiment that stands to be superseded.

And so, at the end of the opera, it is. Bretzner's play ends with Senf, undeterred by his flight's failure, comically advertising pre-subscriptions to his account of his air trip. The opera instead ends with the chorus: 'Viva, viva, to live / and Montgolfier besides! / Music resounds / All cry / They live high! ${ }^{34}$ The affirmative sentiment is especially striking compared with the conclusion of Goldoni's Il mondo della luna, where all sing together, 'in the end he will repent / who would believe in the moon' ('All fin si pentirà / chi lunatica sarà'). Where seeking to go beyond natural boundaries had been opera's recipe for comic downfall, it was - in the wake of ballooning something opera could celebrate.

\section{Fairy-Tale Endings}

If astronomy and aeronautics supplied novel opportunities for musicospectacular display in comic operas that portrayed bourgeois life, however, in the marvellous domains of mythology and fairy-tales they raised a new question: what were the creators of opera to do when their intentionally

33 On the reception of de Rozier's death, see Hallion 2003, 60.

34 'Vivant, vivant sollen leben, / und Montgolfier darneben! / Musik erschalle, / Auf ruft alle, / Sie leben hoch!' Bretzner and Fränzl 1788, 20. 
fantastic devices became the stuff of everyday reality? Such a question became pressing in the milieu of Mozart's Die Zauberflöte. In the summer of 1791, Blanchard was building up to perform the first air balloon launch in Vienna. Two operas inspired by J. A. Liebeskind's story 'Lulu, oder die Zauberflöte', from the third volume of Christoph Martin Wieland's fairytale collection Dschinnistan (1786-9), were conceived for the city at this time: Die Zauberflöte as well as Kaspar der Faggotist, oder Die Zauberzither. Like their source material, both operas feature air transport - but deal differently with the fact that such travel was no longer solely the stuff of myth and fairy tale. Their approaches thus suggest another shift in attitudes towards the operatic potential of science and technology.

In the tale 'Lulu, oder die Zauberflöte', the fairy Perifirime recruits Prince Lulu to recover her magic tinder-box from an evil magician. Like numerous fairy-tales and myths, 'Lulu' features a cloud chariot. After Perifirime gives Lulu a magic flute and ring to help him in his task, a castle door opens by itself and the 'chariot, designed like a cloud' ('Wagen, wie eine Wolke gestaltet'), floats out and lands before them. They get in, and the chariot rises and flies 'as smoothly and quickly as a swallow through the forest'. ${ }^{35}$

The cloud chariot was staple stage machinery for operas based on fairytales or mythology. But when librettist Joachim Perinet wrote Kaspar der Faggotist, oder Die Zauberzither for composer Wenzel Müller and the Theater an der Leopoldstadt, he turned the cloud chariot into a 'hot air balloon' ('Luftballon' or 'Luftmaschine'). As in 'Lulu' (but for some name changes), the fairy Perifirime charges the Prince Armidoro with retrieving a golden tinder-box that the Sorcerer Bosphoro has stolen from her. After bestowing upon Armidoro a magic zither and magic ring, Perifirime and her genies present the prince and his comic sidekick Kaspar with a hot air balloon. The balloon appears at a wave of Perifirime's hand, as she tells Armidoro and Kaspar: 'this hot air balloon will take you comfortably to the spot'. ${ }^{36}$ The moment is exploited for comic effect: Kaspar circles the basket sceptically and expresses trepidation at getting inside, but Armidoro commands him to be brave, and they fly off to Bosphoro's palace.

While Die Zauberflöte also features a prince (Tamino) and comic sidekick (Papageno) sent on a rescue mission equipped with magical gifts, the

\footnotetext{
35 'Der Wagen erhob sich, und flog so sanft und schnell wie eine Schwalbe über den Walde hin.' Wieland 1789, 3:298.

36 'Dieser Luftballon wird euch bequem an Ort und Stelle bringen.' Perinet 1792, 15.
} 
flying machine is not among the tools put at their disposal. Instead, they are told that, 'three boys, young, handsome, / noble and wise / will hover around you on your journey; / They will be your guides; / follow only their advice. ${ }^{37}$ At critical moments in the unfolding drama, these three boys appear in a flying machine (Flugwerk). Numerous commentators claim that at the premiere of Die Zauberflöte, this flying machine was made to look like a hot air balloon. And in a number of modern productions including at the Hamburger Staatsoper (1971), Opéra National de Paris (2001), Houston Grand Opera (2003) and in Ingmar Bergman's 1975 film version - the three boys descend in the 'period' apparatus; Figure 8.2 shows a further example from 2013.

Yet, the claim that a hot air balloon graced the stage at the premiere of Die Zauberflöte circulates without evidence, and seems to be a spurious invention of later critics who connected the Flugwerk with Blanchard's contemporaneous ascent. David J. Buch has observed that interpretations of Mozart's Die Zauberflöte have largely proceeded without considering the generic context of fairy-tale opera - a context that, when recovered, shows many supposedly Masonic elements of the opera to be conventional fairy-tale elements. ${ }^{38}$ The putatively 'aeronautic' Flugwerk was similarly a fairy-tale opera convention. Already in the 1770 s, one finds comic theatre pieces touting Flugwerken in their generic descriptions, and the devices routinely joined other fantastic elements on the stage. $^{39}$

Not for lack of knowledge would the creators of Die Zauberflöte have preserved the traditional flying machine rather than update it to a hot air balloon. Five years earlier, Immanuel Schikaneder had authored a Singspiel for the occasion of Baron Lütgendorfs planned Augsburg launch. Set to music by Benedikt Schak (the first Tamino), Der Luftballon centres on the multi-suitored Sophie and an aeronaut who fly together and thereafter declare the true love - founded not in financial interest but in 'harmony of soul' - that they feel for one another. A less idealised vision of balloon flight

37 'Drei Knäbchen, jung, schön, / hold und weise, / Umschweben euch auf eurer Reise; / Sie warden eure Führer sein; folgt ihrem Rate ganz allein.' All translations from Die Zauberflöte are after Frey 1997.

38 Buch 2004.

39 A 1773 play mocked standing conventions by imagining a piece with the excessive title, 'Leander und Hero, oder der Ueberwinder des Konigs Zamar durch Zauberey, oder die treue Liebe, oder nichts umsonst; eine Heldenkumedie [sic] mit Flugwerken, Maschinen, Verwandlungen, Teufeln und Gespenstern' (Leander and Hero, or the conqueror of King Zamar through magic, or the true love, or not for nothing; a heroic comedy with flying machines, machines, transformations, devils and ghosts); Moll 1773, 12. 


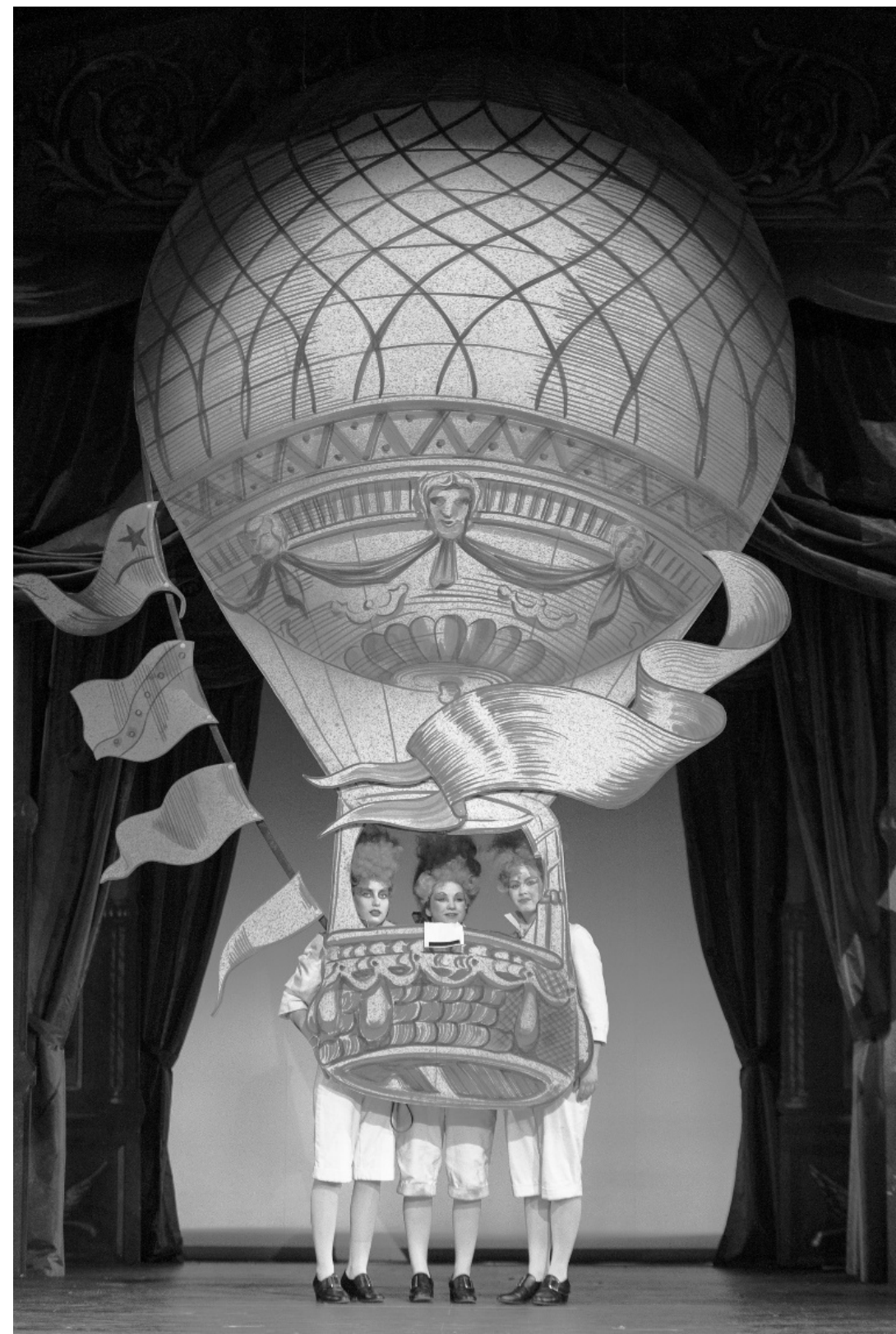

Figure 8.2 'Drei Knaben', press photo from the 2013 Theater und Orchester GmbH production of Die Zauberflöte, Neubrandenberg/Neustrelitz. Photo credit: Joerg Metzner. 
comes from Mozart himself. On 6 July 1791 - the day Blanchard made his successful ascent in Vienna, after having failed on 9 March and 29 April Mozart wrote to his wife: 'even as I write these lines Blanchard will either ascend into the air or fool the Viennese for a 3rd time. This whole episode with Blanchard is most unwelcome to me, today of all days - it's preventing me from completing my business. ${ }^{30}$

The simple prop of a flag - specified for the aeronauts in both Schikaneder and Bretzner's texts, and ubiquitous in period images - would have been sufficient to turn the Flugwerk into a hot air balloon. But no flags are mentioned; instead, the three boys are described as carrying silver palm branches, their Flugwerk bedecked with roses. In light of Kaspar, der Faggotist - the main rival for Schikaneder and Mozart's production - the Flugwerk in Die Zauberflöte appears a deliberate decision not to engage with the balloon craze. The different approaches to operatic flight in an aeronautic age may have much to do with timing: Kaspar premiered on 8 June 1791, when Blanchard had yet to successfully ascend in Vienna, and balloon flight still had the status of a fantastic dream. Zauberflöte premiered on 30 September 1791, nearly three months after Blanchard's flight, when balloon flight was a fading memory - the stuff of a new normality.

Today, the obsolescence of hot air balloons grants them much the same status they enjoyed in their pre-normalcy days: they readily read as a fantastic image from a world that is not ours. In this respect, the hot air balloon now makes a fitting 'flying machine' for the three boys. But it is also worth considering the difference a hot air balloon makes for a period reading of the opera. At the start of the Act II finale, 'the three boys descend' ('die drey Knaben fahren herunter') to an instrumental introduction magically scored for clarinets, bassoons and horns, sotto voce (Example 8.6). Then they sing:

$\begin{array}{ll}\begin{array}{l}\text { Bald soll der Aberglaube schwinden, } \\ \text { Bald siegt der weise Mann. }\end{array} & \begin{array}{l}\text { Soon shall superstition disappear, } \\ \text { Soon the wise man wins. } \\ \text { O, holde Ruhe, steig hernieder, }\end{array} \\ \text { Kehr in der Menschen Herzen wieder, } & \begin{array}{l}\text { O gracious peace, descend here, } \\ \text { Return to the hearts of people, }\end{array} \\ \text { Dann ist die Erd' ein Himmelreich, } & \text { Then is the Earth a heavenly kingdom, } \\ \text { Und sterbliche sind Göttern gleich, } & \text { And mortals like gods. }\end{array}$

To unite these words with a hot air balloon is to put technology forward as the means to make 'mortals like gods'. To unite them with a cloud chariot is to figure mortals becoming 'like gods' as the attainment of peace rather than

${ }^{40}$ Letter of 6 July 1791; quoted in Abert 2007, 1210. 
Example 8.6 Mozart, Die Zauberflöte, Act II finale, 'Bald prangt, den Morgen zu verkünden'; instrumental ritornello while 'the three boys descend'

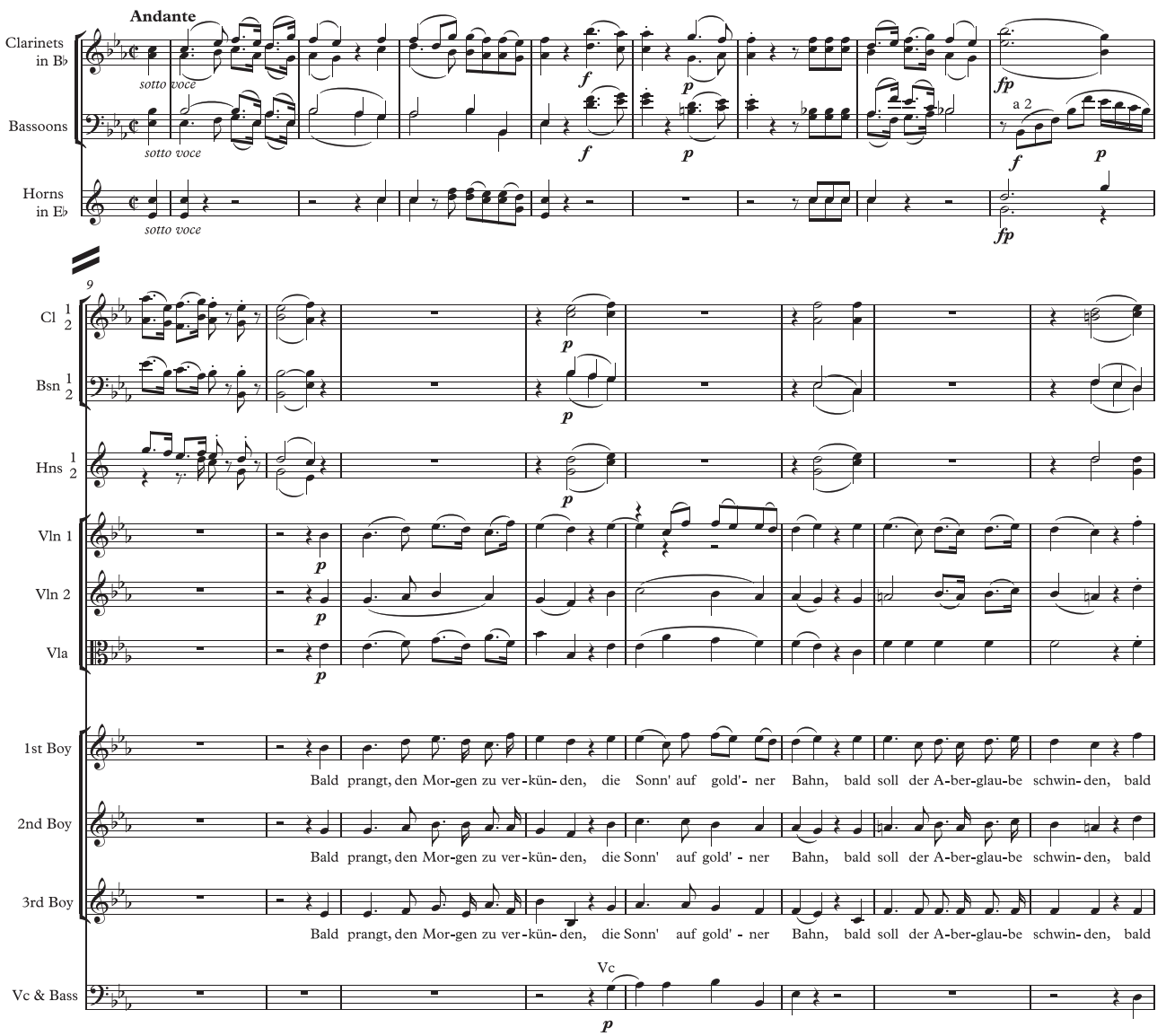

power - the difference between Mozart's gentle wind ensemble, and Fränzl's pedal-point crescendo.

In the decades before the Montgolfier brothers unleashed their balloons, flight seemed like childish fantasy - especially so on the operatic stage, where flying chariots were a staple of the marvellous that critics seeking a more naturalistic theatre targeted for censure. In retrospect, however, one can see these flying gods and goddesses not as mere 'puerile representations', as Charles Burney described them in 1773, but as stimuli to technological innovation. As Sigmund Freud suggested amidst the swirling changes of the early twentieth century, 
'these things that, by his science and technology, man has brought about on this earth ... do not only sound like a fairy tale, they are an actual fulfilment of every - or of almost every - fairy-tale wish'. ${ }^{41}$ To put it another way, fairy tales and myths have been incubators for science and technology, helping to set research agendas by archiving dream images of superhuman powers.

Through its stagings of fairy tales and myths, opera has been a site of cross-fertilisation between technological innovations and dream images, and also a site for social commentary on the practice of scientific inquiry. The 1770s-80s mark a remarkable phase in this operatic history, when hard-edged rejection softened to make room for the pleasures of observation, and the possibility that the pursuits of knowledge and of love need not stand in conflict. The Flugwerk of Die Zauberflöte stands for the end of this phase, when to re-enchant the operatic stage, developments in science and technology were relegated to the wings, to discourses of reception, to performance training and to subtexts - where they can be found in abundance throughout the nineteenth century.

${ }^{41}$ Freud 1989, 737. 